\title{
$\operatorname{IgG}$ サブクラス低下の 4 症例
}

中田順子・大追 茂人・迫正廣*

\section{IgG Subclass Deficiency in Patients \\ with Upper Respiratory Tract Infection}

\section{Junko Nakata, Shigeto Osako and Masahiro Sako \\ (Children's Medical Center of Osaka City)}

Immunodeficiency syndromes are considered to be responsible for some intractable infections of the ear, nose or throat.

In Japan, however, there have been only a few reports of IgG subclass deficiency.

This is a report of four cases of chronic or recurrent respiratory infection considered to be related to low serum levels of IgG subclass.

In two patients with purulent rhinorrhea and productive cough the diagnosis was chronic sinusitis, bronchiectasis and OME. Haemophilus influenza was isolated in sputum cultures. One patient had selective $\operatorname{IgG}_{2}$ deficiency and the other patient had a low serum $\operatorname{IgG}_{4}$.

The third patient had prolonged otitis media, had low serum $\operatorname{IgG}_{3}$ and a diagnosis of Prader-Willi syndrome, the fourth had recurrent otitis media, low serum $\operatorname{IgG}_{4}$ and a diagnosis of Wiskott-Aldrich syndrome.

Monthly intravenous injections of human immunoglobulin with high concentrations of the deficient subclass and appropriate antibiotic therapy brought about cures of their infections.

Key words: immunodeficiency disease, IgG subclass deficiency, $\operatorname{IgG}^{2}$ deficiency, $\mathrm{IgG}^{3}$ deficiency, $\mathrm{IgG}^{4}$ deficiency

\section{はじめに}

難治性耳鼻咽喉科疾患の中には，免疫不全症 が存在することは知られている112)。なかでも IgG subclass 欠損症による報告 ${ }^{3 / 4) 5}$ は，我国 ではまだ少ない，今回，慢性あるいは頻回に繰 り返す上気道感染症例の中に存在した IgG subclass 低下または低下傾向のみられた 4 症 例を経験したので報告する.

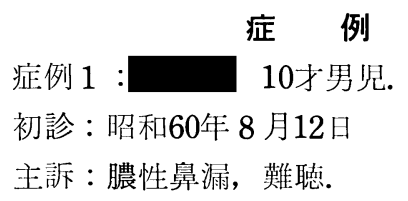

現病歴：乳児期より，約 1 力月に 1 回程度の 熱発を繰り返していたが，6才洔に近医にて肺 野の異常除影を指摘された。同じ頃より呼んで も返事が遅く, 常に膿性鼻漏, 鼻閉が続いてい たため来科した。 
局所所見 : 鼻腔内には, 両側共, 膿性鼻漏が 充満し, 両下鼻甲介の発赤と腫脹を認めた. また，両鼓膜は，暗青色飞混濁し，いわゆる

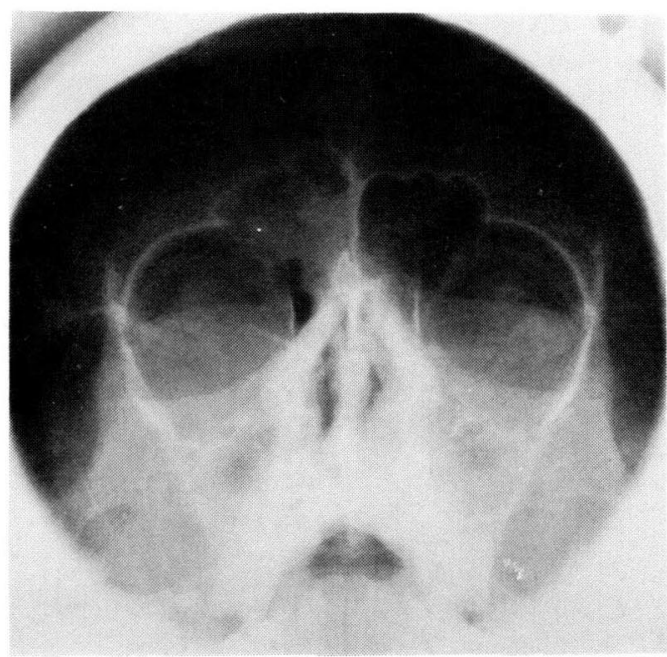

図 I 症例 1 の Waters 撮影 両側上顎洞粘膜の腫脹がみられる.

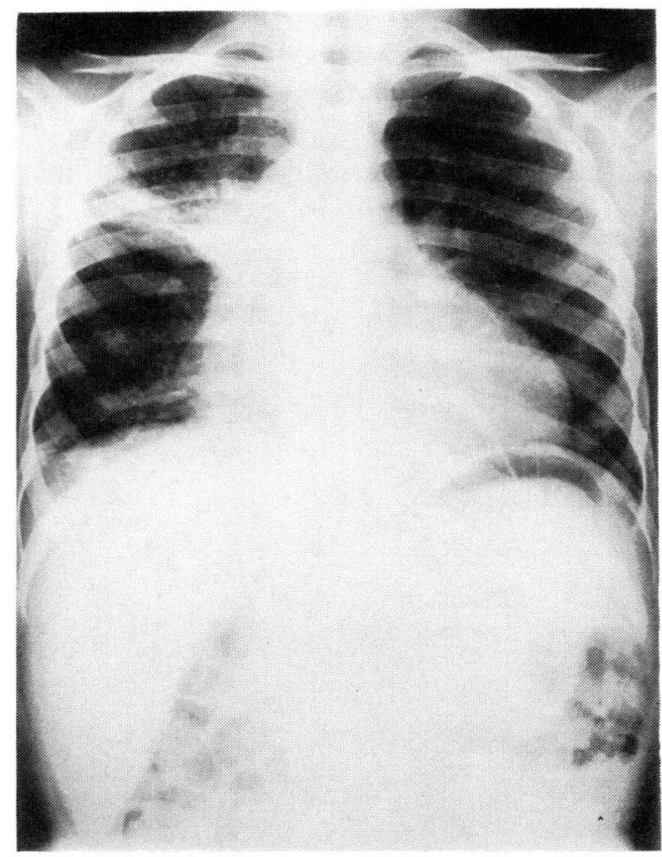

図 2 症例 1 の胸部正面像 右下肺野にかけての浸潤影と miner fissure の 消失を認める. glue ear の状態であった.

検査所見 : 副鼻腔 $\mathrm{X}$ 線撮影では, 両上顎洞及 び両管骨洞に陰影を認めた（図 1 ）。聴力検査 では, 4 分法で右 $41.25 \mathrm{~dB}$, 左 $43.75 \mathrm{~dB}$ の 聴カレベルで tynpanogram は両側 B type の中等度伝音性難聴を示した。 また，胸部 X 線 撮影では主に肺門から右下肺野にかけての浸潤

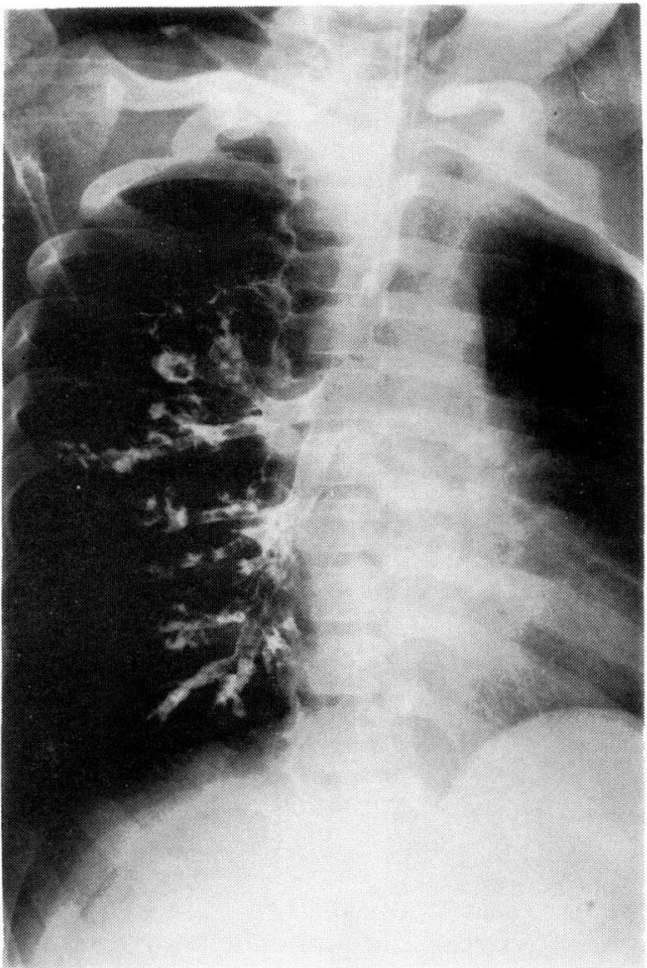

図 3 症例 1 の気管支造影（右斜位像）末梢気 管の拡張が著明である。

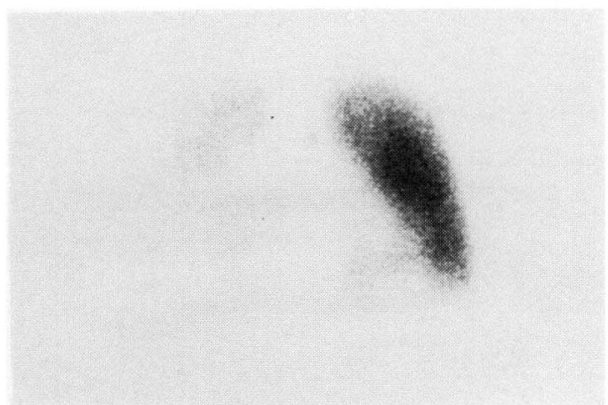

図 4 症例 1 の肺血流シンチ 右肺血流は著明に低下している。 
影 miner fissure の消失を認めた（図 2 ). 気 管支造影を施行したとこ万, 未梢気管支の棒 状, 数珠状の拡張が著明であった（図 3 ).

血流シンチでは，右肺の血流は著明に低下し ていた（図 4)。 ${ }^{133} \mathrm{Xe}$ ガスによる換気シンチ において，右肺だけでなく，左肺にも wash delay を認めた。血流スキャンと换気シンチ とがほぼ一致することにより気道系の朕患であ ることが示鄍された。尚，喀咨の細菌検丕では H. influenzae が検出された.

免疫グロブリン值及び各種怂疫機能検查は正 常であったが, IgG subclass 定量 (Miles 社 製 IgG subclass RID）では $\mathrm{IgG}_{2}$ の薯仃な 低下を認めた（表 1 ）。

治療としては, 症例 1 亿対して, 喀痰培等の 絬果，感受性のあった $\mathrm{ABPC} 1 \mathrm{~g} \times 3 /$ 日（100 $\mathrm{mg} / \mathrm{kg} /$ 日）と $\mathrm{GM}(5 \mathrm{mg} / \mathrm{kg} /$ 日）とと屯にポリ エチレングリコール処理した㑆疫グロブリン (以下阔品名 Venoglobulin-I と畍す) $3 \mathrm{~g} /$ 日 $(100 \mathrm{mg} / \mathrm{kg} /$ 日）を 5 日閒投与後, 膿性鼻漏之膿 性痰の㳚少を待って全麻下に，両挕腔チュ一 ブ留㯰術を施行した。退院後も頻回の喀桨敃よ
び膿性鼻漏の細菌感受性テストを施行し，そ のつぞ，感受性ある抗生物質の併用とともに Venoglobulin-I $100 \mathrm{mg} / \mathrm{kg}, 200 \mathrm{mg} / \mathrm{kg}$ もし くは， $400 \mathrm{mg} / \mathrm{kg}$ までの大量投与を 1 力月に 1

日 1 回実施した。

症例 2 : 6才女览.

初榜：昭和 60 年 8 月 9 日

主訴：膿性鼻漏，膿性痰，難恥。

現病歴：2才頃より断続的な陔を繰り返し， 6 才になり，陔とともに粘液性の膿性资を喀出 するようになった。また，近医耳鼻咽喉科にて 慢性副鼻腔炎, アデノイド増殖症を指摘され来 科した。

刑所所兕：鼻腔内には，膿性鼻漏の充蔽とと もに，「挖では後鼻漏を認めた。雨鼓膜は陥凹 と沘濁を示し，動きむ不坟であった。

検枯所見：㨽鼻腔 $\mathrm{X}$ 線撮影では，両上顎洞及 び両篩骨润に障影を認め，恥力検査では 4 分法 で，右 $40 \mathrm{~dB}$, 左 $36.25 \mathrm{~dB}$ の中等度伝音性難 恥を示した。胸部 X線撮影では，右下肺野内側 に㳇潤影を認め，心陰影が不鮮明であり，右中 葉下禁全区域の病変が疑われた。断層撮影で

表 I 4 症例の各免疫ブロブリン值と IgG subclass 值

\begin{tabular}{|c|c|c|c|c|c|c|c|c|c|c|}
\hline & \multirow{2}{*}{ Patient } & \multirow{2}{*}{ Age $/$ Sex } & \multirow{2}{*}{ Diagnosis } & \multicolumn{7}{|c|}{$\mathrm{mg} / \mathrm{d} \ell$} \\
\hline & & & & $\mathrm{IgG}_{1}$ & $\mathrm{IgG}_{2}$ & $\mathrm{IgG}_{3}$ & $\mathrm{IgG}_{4}$ & $\mathrm{IgG}$ & $\operatorname{Ig} A$ & $\operatorname{Ig} M$ \\
\hline 1 & & $10 \hat{\delta}$ & $\begin{array}{l}\text { chronic sinusitis } \\
\text { bronchiectasis } \\
\text { otitis media } \\
\text { exsudativa }\end{array}$ & 638 & $55^{*}$ & 78 & 50 & 969 & 130 & 63 \\
\hline 2 & & 6 우 & $\begin{array}{l}\text { chronic sinusitis } \\
\text { bronchiectasis } \\
\text { otitis media } \\
\text { exsudativa }\end{array}$ & 1280 & 98 & 22 & $<3^{*}$ & 1382 & 109 & 308 \\
\hline 3 & & 6 今 & $\begin{array}{l}\text { Prader-Willi syn. } \\
\text { Prolonged } \\
\quad \text { otitis media }\end{array}$ & 719 & 256 & $11^{*}$ & 55 & 1107 & 203 & 57 \\
\hline 4 & & 5 今 & $\begin{array}{l}\text { Wiskott- } \\
\text { Aldrich syn. }\end{array}$ & 612 & 243 & 28 & $6^{*}$ & 623 & 47 & 25 \\
\hline
\end{tabular}


は，やや肥厚した気管支が末梢まで認められ， その周辺には帯状の浸潤像がみられた。鼻漏の 細菌検査では H. influenzae が検出された. 免疫グロブリン值及び各種免疫機能検査は正 常であったが $\mathrm{IgG}_{4}$ の低下傾向を認めた（表 1 ). 治療としては, 喀痰と膿性鼻漏に感受性 のあった CEM 0.5 g × 41日 (100mg $/ \mathrm{kg} /$ 日) と GM $50 \mathrm{mg} \times 21$ 日 $(5 \mathrm{mg} / \mathrm{kg} /$ 日) 飞加えて Venogloblin-I $2 \mathrm{~g} /$ 日 $(100 \mathrm{mg} / \mathrm{kg})$ を 5 日間投与後, 全麻下に手術が可能になり, アデノイド切除術 を施行した。退院後は, ムコソルバン $60 \mathrm{mg}$ 分 四, 小柴胡湯 $5.0 \mathrm{~g}$ 分二之葛根湯加川芦辛夷 $5.0 \mathrm{~g}$ 分二とと屯に, 喀痰増加洔には $\mathrm{CCL}$ $100 \mathrm{mg}$ 分四投薬しているが，测鼻腔陰影や胸部 異常陰影増強時には，そのつど感受性ある抗生: 物質と Venoglobloblin-I $2 \mathrm{~g} /$ 日 $(100 \mathrm{mg} / \mathrm{kg})$ を点滴静注している.

症例 $3:-6$ 才男児.

初診：昭和 60 年 11 月 15 日

主訴：反復性中耳炎.

現病歴：生後まもなく哺乳力低下と低片糖に よるけいれんを抢てし, 成長につれて筋力低下 が著明になった。また，2才頃より雨急性聑 炎を反復し，熱発をくり返していたが，右耳䨕 が持続し, 精查, 加療の目的で入院した. 尚, 患児は小児科で Prader-willi syn. と診断さ
れていた（表2）.

局所所昌：右鼓膜穿孔とともに鼓室腔内に存 在する肉芽が明らかで, 病変が長期閒にわたる ことを思わせた，凂疫グロブリン值及び各種负 疫機能検烃は正常であったが, $\mathrm{IgG}_{3}$ の低下倾 向を示した（表1)。治療としては，中耳炎に 対して, 耳漏の細菌検査で感受性のあった AS TM $80 \mathrm{mg} \times 3 /$ 日 $(5 \mathrm{mg} / \mathrm{kg} /$ 日) と PIPC $1.5 \mathrm{~g}$ $\times 3 /$ 日 $(100 \mathrm{mg} / \mathrm{kg})$ に加えて Venoglobulin-I $5 \mathrm{~g} /$ 日 $(\fallingdotseq 100 \mathrm{mg} / \mathrm{kg} /$ 日 $)$ を 5 日間点激静注によ

り耳漏消失, 鼓膜が閉鎖し完治した.

症例 4：—5才男児.

初診：詔和57年 7 月 24 日

主訴: 鼻出林, 反復性巾耳炎.

现病歴：生下侍より出㑑斑に父づき, 生後 1

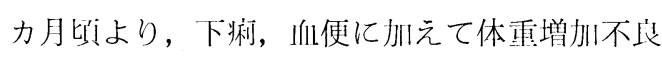
屯频葆であった．生後 5 力月顷より，叫肢の屁 侧部を川心に全身にアトピー椂湿渗が出現し， 某病院を受診した。精査の絬果，荐明な血小板 減少が明らかになり wiskott-Aldrich syn. 之診断された（表 3 ).

4 才 8 力月頃より，既存の症状に加えて鼻出

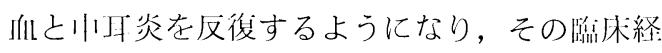
過と治瘏纱法を四 5 に亦した。

局听所见：雨鼻腔内は，キーゼルバッ八部位。

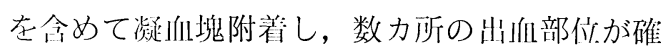

表 2 Prader-Willi 症候群の通常みられる主要症状

1.PW Sの診断に必須の症状
(1) 乳児期の筋緊張低下
(2) 性腺発育不全
(3) 肥満
(4) 精神遅滞
(5) 特異顔貌
（6）遺伝的背景を考慮した上での低身長

2. 50〜90\%の PW S 患者にみられる症状
(1) 小さい手足
(2) 皮膚疾患
(3) 歯科疾患
(4) 新生児期の啼泣の異常
(5) 脊柱側彎症
(6) 斜視

(7) 嘔吐困難

(8) 食物に関連した行動異常

3.10〜50\%の PW S患者にみられる症状
(1) 異常分姢歴
(2) 近視
(3) 不明暸な発音
(4) 痛み刺激に対して鈍感

4. 10\%以下の PW S患者にみられる症状
(1) 先天性股関節脱下]
(2) 頭用桩大
(3) 糖尿病
(4) 易骨折症
(5) 痙攣性疾患 

(A) 臨床像
1 伴性劣性遺伝で, 男子のみ発症する.
(2) 生後まもなくから出血性素因が現われ，血便， 吐血, 紫斑, 溢血を生ずる.
(3) 湿帘
(4) 化膿菌, ウイルス, 真菌類, Pneumocystis carinii など, ほとんどすべての病原因子に 感染感受性が高い.とくに, herpes, cyto- megalovirus などの全身感染を生ずる危険 があり，水痘も重症化する。
5 乳幼児期に出血, 感染のいずれかで死亡する ものが多いが，その後リンパ網内系の悪性腫 瘍の発生頻度が高まり, 多くは10才以前に死 亡する。
(B) 一般検查所見
(1) 末梢血小板数は减少（通常 7 万以下）してい るが，骨髄巨核球数は正常である。 また血小 板機能（凝集能, 粘着能）は低下している.
2 しばしば好酸球增多をみる。
(3) 循環リンパ球数は正常ないし減少している.

(4) 同種血球凝集素の欠如するととが多い.

(C) 確認彰断のための検查所見

(1) IgG 濃度は正常であるが，IgM 濃度はや や低いてとが多く, IgA と IgE は上昇して いる例が多い，特に IgE は著増する場合が ある。

2 一般の抗体産生能は正常に認められるが，多 糖体抗原に対する抗体産生能に障害が認めら れる。

(3) 遅延型過敏反応，P H A 反応などの細胞性免 疫能は減弱しているととが多いが，陽性反応 がえられる場合もある。

4 胸腺は多少萎縮しているが, Hassall 小体の 数は正常で, 皮髄の分化もよい場合が多い。 しかし著明な形成不全を認める例もある。

5 末梢リンパ節の像は ataxia telangiectasia での記載内容とよく類似している.しかし重 症複合免疫不全症のように濾胞の形成もなく， 全般的にリンパ成分の乏しい例もありうる。

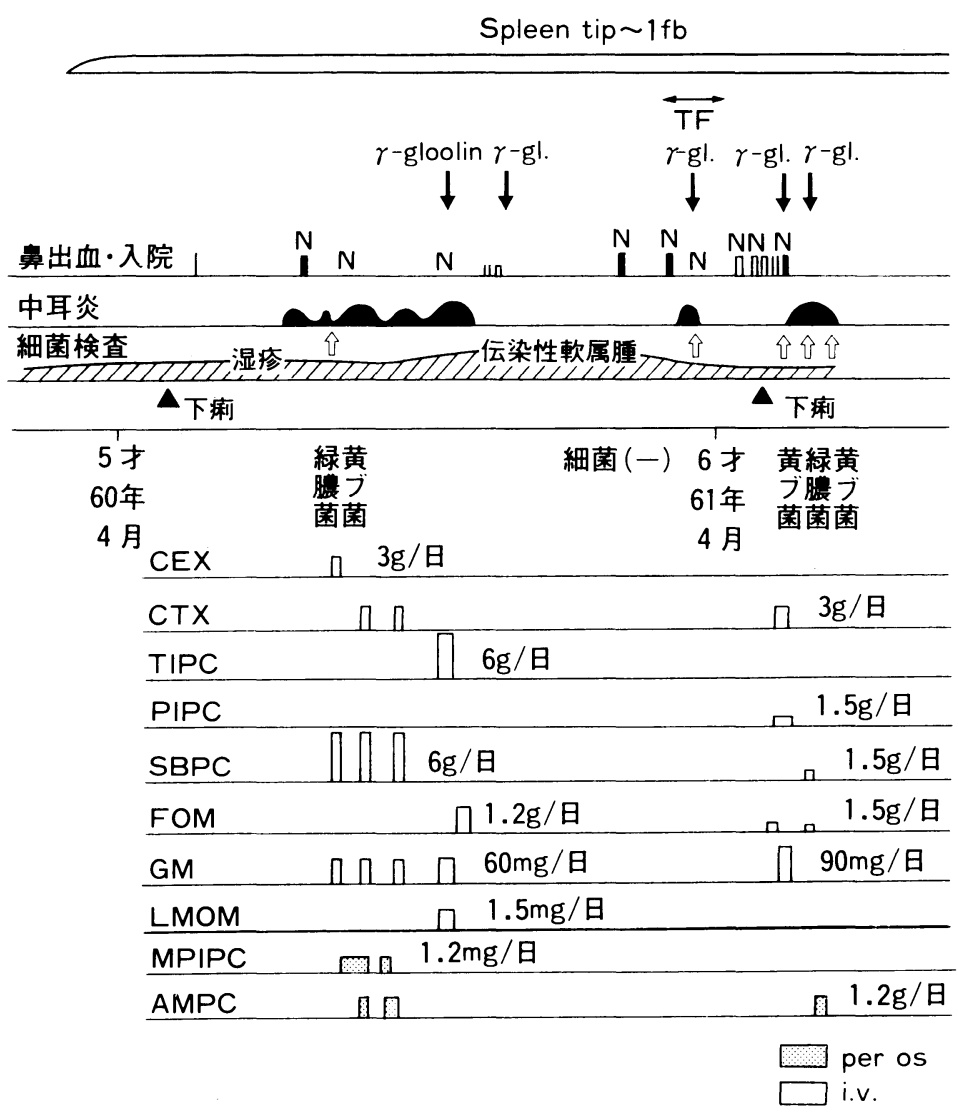

図 5 症例 4 の中耳炎を反復するようになった頃よりの臨床経過と治療方法 
認された。また，両鼓膜は穿孔し，膿性耳漏の 流出がみられた。

検査成績：血小板は 3.2 万と少なく，平均血 小板体積むやや小さく, 血小板凝集能も低下し ていた，免疫グロブリン值では， IgA, IgG はほぼ正常範囲内であったが，IgM の峄度減 少を認め, 同種血球凝集素価は 4 倍であった。 また，末梢血リンパ球数，リンパ球 subpopulation は正常範囲であったが, リンパ球 subset では $\mathrm{OKT}_{4}$ がやや低值を示した.

カンジダによる羊延型皮䖉反応はいずれも䧔 性であった．以上の所見に加えて $\mathrm{IgG}_{4}$ の低 下傾向を示した。治療経過は図 5 に示してい る. 急性中耳炎の反復の際に感受性ある抗生物 質とともにVenoglobulin-I 400mg/ $\mathrm{kg} /$ 日 5 日 間投与により，一時的に耳漏の減少または消失 をみた。

\section{考察}

1964年 Grey \& Kunkel ら ${ }^{6}$ は，ヒト IgG が polypeptide heavy chain の抗原性の造 いを基に 4 つの subclass に分かれることを報 告し, それらが1966年 $\mathrm{WHO}^{7)}$ によって $\mathrm{IgG}_{1}$, $\mathrm{IgG}_{2}, \mathrm{IgG}_{3}, \mathrm{IgG}_{4}$ と命名された。1968年, 1969年には Terry ${ }^{8)}$ とYoung ${ }^{9)}$ らは反復感 染を拈こす患者に拈いて IgG subclass 火損 の variation の存在を指摘した。 その翌年に は Schur ${ }^{10)}$ らは IgG subclass の選扒的に 久損している患者は細菌感染や進行性肺炎を おこすととを報告した。また Oxelius は1974 年 ${ }^{11)}$ には $\mathrm{IgG}_{2}$ と $\mathrm{IgG}_{4}$ が遗伝的に欠損する 家系に反復感染を打ししやすいととを発见し， 1979年 ${ }^{12}$ にはcartilage-hair-hypoplasia syn. などの免疫不全症患者における IgG subclass の定量化を実施し，その 2 年後 ${ }^{13)}$ には Berkel や Hanson とと屯に ataxia telangiectasia 患者に随判する IgG 欠损を見い出し, 同年 ${ }^{14)}$ $\mathrm{IgG}_{2}-\mathrm{Ig} \mathrm{A}$ 久損の其存が多い事在報㸃してい る. 以上の上うに難治性感染症に打ける IgG subclass の低下は興味深い。

今回報告した 4 症例のうち, 症例 $1 \sim 3$ はい
ずれも晌海総 IgG と各種免疫機能検查は正常 簌囲にあるにもかかわらず IgG subclass の低 下をみている. 図 6 亿各症例の subclass 值を 図示している.

症例 1 では，正常児の平均以下の $\mathrm{IgG}_{2}$ の 低下を涊めた。症例 2 では $\mathrm{IgG}_{4}$ の低下傾向 を示した.いずれも臨床症状はよく似ており sinobronchial infection の形をとり, 喀痰又 は鼻漏培答において共に H. influenzae が検 出された. polysaccharide 抗原に対する抗 体を作る分再の大部分は $\mathrm{IgG}_{2}$ に属するため $\mathrm{IgG}_{2}$ 火損例では, polysaccharide の莢膜を 有する H. influenzae 等の感染に対して抵抗 性が弱いと報华1516) されているが, Beck と Heiner ${ }^{17)}$ は $\mathrm{IgG}_{4}$ 首独欠損例についても severe pulmonary infection 症例を報告してい る. 2 症例其胸部隍影が消失しないにもかかわ らず，现在小㻖状態を保っている.

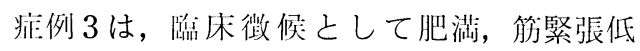
下，停留等丸をもち Prader-Willi syndro$\mathrm{me}^{18)}$ と診断された患児である。遷延性中耳炎 で治療に抵抗した。一般的に Prader-Willi syn. に拈いて罗感染倾向は報告されていな いが，この忠乔に打いては $\mathrm{IgG}_{3}$ 低下による bacterial や viral の蛋白抗体の低下と肥満に よる耐糖能低下が長期にわたる慢性中耳炎の原 因ではないかと考えている.

症例 4 は Wiskott-Aldrich $\operatorname{syn}^{19)}$. 症例で ある. IIII清 IgG 值は正常值を示した. IgM の低下のみならず細胞性免疫能の低下, $\mathrm{IgG}_{4}$ の低值を示し, 免疫不全症に随伴し, IgG subclass 低值と考元られた症例である.

一般に $\mathrm{IgG}_{4}$ に関して，正常人においても 他の IgG subclass に比較し，バラツキが大 きいため, 量的比較には異諭があると考えられ ているため, 症例 2 之症例 4 亿ついては低下傾 向とした。一般に IgG は heavy chain のポ リペプチド鎖の抗原性の差により $\mathrm{IgG}_{1}-\mathrm{IgG}_{4}$ に分けられ，正常血清中の構成比率は $\mathrm{IgG}_{1} 60$ $\sim 70 \%, \mathrm{IgG}_{2} 14 \sim 20 \%, \mathrm{IgG}_{3} 4 \sim 8 \%, \mathrm{IgG}_{4}$ 
2〜6\%であり，各々の IgG subclass はその Fc 部分が独自な生物学的特性を示すといわれ ている. 各々の生物学的特性 ${ }^{20121}$ を表 4 亿示し た. $\mathrm{IgG}_{1}$ ¿ $\mathrm{IgG}_{3}$ には protein antigen(bacterial, viral, antologous protein) する抗
体が存在し 22)23124), IgG 抗原に対する抗体に富んでいる。 また，アレル ギー患者や減感作療法中の患者では $\mathrm{IgG}_{4}$ が 高值を示す例が多いこと河が報告されている. しかし，なお，それぞれの役割については未解
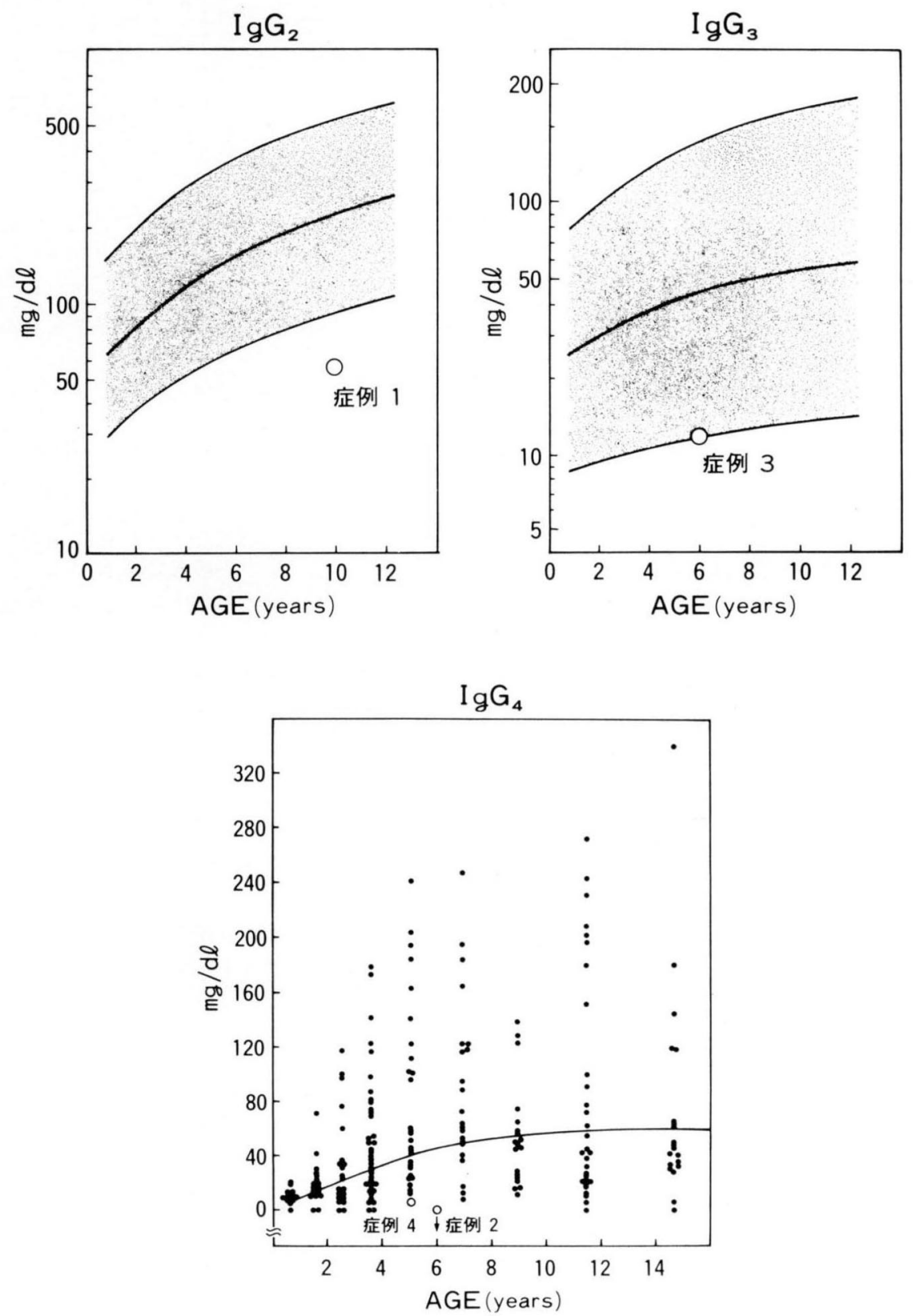

図 6 IgG subclass の正常範囲と 4 症例における検査值を示す. 
表 4 IgG subclass の生物化学的性状

\begin{tabular}{|c|c|c|c|c|}
\hline & $\operatorname{IgG}_{1}$ & $\operatorname{IgG}_{2}$ & $\mathrm{IgG}_{3}$ & $\operatorname{IgG}_{4}$ \\
\hline 分 子 量 & 146,000 & 146,000 & 165,000 & 146,000 \\
\hline 成人平均血清濃度 $(\mathrm{mg} / \mathrm{dl})$ & 840 & 240 & 80 & 40 \\
\hline IgG 中の比率 $(\%)$ & 70 & 20 & 7 & 3 \\
\hline 半 減 期 (日) & 25 & 23 & 9 & 25 \\
\hline $\mathrm{Gm}$ マーカー & $\begin{array}{c}1,2,4,7 \\
17.18,20,22\end{array}$ & 23 & $\begin{array}{l}5,6,10,11, \\
13,14,15,16, \\
21,24,25\end{array}$ & \\
\hline 胎盤通過性 & $(+)$ & $( \pm)$ & $(+)$ & $(+)$ \\
\hline 補 体 結 合 性 & (H) & $(+)$ & (m) & $(-)$ \\
\hline $\begin{array}{l}\text { タンパク融解 (papain clcavage) } \\
\text { に対す受性 }\end{array}$ & $(+H)$ & $( \pm)$ & (HII) & (H) \\
\hline プロテインA結合性 & $(+)$ & $(+)$ & $(-)$ & $(+)$ \\
\hline 電気的易動度 & slow $r$ & fast $\gamma$ & $r$ & fast $r$ \\
\hline
\end{tabular}

決な点も多い。

治療として，4症例其，感受性ある抗生物質 似问に加えて，䍀消 $\operatorname{IgM}$ の低下と $\mathrm{OKT}_{4}$ の 低下を示した。

とともに恐疫グロブリン $100 \mathrm{mg} / \mathrm{kg} /$ 日， $200 \mathrm{mg} /$

$\mathrm{kg} /$ 日 又は $400 \mathrm{mg} / \mathrm{kg} /$ 口の併用療法を行い， なかでも症例 1 に対しては，每月 1 回，約 2 年

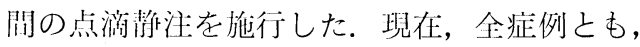
感染という而では，経過应好である，その治 療に際して使用する㪇疫グロブリンは，処理 方法により IgG subclass の棈成比率が晎な る26)ため，目的とする subclass が含まれる製 剂を選ぶ必要がある，以上のように奞治性耳鼻 咽喉科疾患に遭遇した豩合に，免疫グロブリ ン値及び各種凭疫機能検査は正常であっても IgG subclass 低值という minor な凭疫不全 状態が易感染の原因となりうるととを念䫓に入 れて治療にあたるべきであることを弰感した。

\section{まとめ}

1. 難治性耳鼻咽啖科矨患の山にみられた IgG subclass 低下 4 症例について報告した。

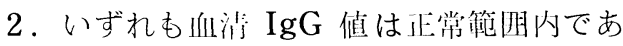
った.

3. $\mathrm{IgG}_{2}$ 低下症例 と $\mathrm{IgG}_{4}$ 低下倾问を認め た 2 症例に打いて気通よりの分泌物から $\mathrm{H}$. influenzae が検出された.

4. 反後性中耳炎を示した症例は WiskottAldolich syndrome と診断され $\mathrm{IgG}_{4}$ の低下

本論文の要旨は，第15回日本小児耳莮咽晚科研究会 で発表した。

\section{参考文献}

1) 奥田 稳：负疫学的検查法および治燎法. 皮䖉・ 眼・耳鼻咽唉科垸患免疫学的検査の有用な耳鼻咽 喉科疾患. 臨床医 II：10；2154 2155，1985.

2 ) 小松信行, 新川 敦, 宮永 守, 他: 中耳炎の再 発で気付いた無ガンマブロブリン血症の一例．臨 床耳科 13：1；490４91，1986.

3 ) 中尾 亨: 選択的 IgG 欠損症. 医学のあゆみ 117:119, 1981 .

4) 東 寛, 佐々木暢彦, 向井直樹： IgA 低下症 に $\mathrm{IgG}_{2}$ 欠損を伴った 1 例. 日本小児科学会雑 誌 $87 ： 5 ； 874 \sim 875,1983$.

5 ) 井関幹郎：IgG サブクラスの欠乏症. 小児科 MOOK 43. 103 110頁, 金原出版, 東京. 1986.

6) Grey HM and Kunkel HG : Hchain subgroups of myeloma proteins and normal $7 \mathrm{~s} r$ globulin. J exp Med I20:253 266, 1964 .

7) WHO : Nortation for human immunoglobulin subclasses. Bull Wld Hlth Org 35:953, 1966. 
8) Terry WD : Variation in the subclasses of $\mathrm{IgG}_{1}$ immunoglogic deficiency diseases in man. Birth Defects Original Article Series Vol 4 No 1. (ed by In Bergsma D). pp 357 363, The Nationla Foundation, New York, 1968.

9) Yount WJ, Hong R, Seligmann M, et al : Structural gene defects and preponderance of $\mathrm{IgG}_{3}$ subgroup in patients with hypogammaglobulinemia. J Clin Invert $48: 92 a$, 1969.

10) Schur PH, Borel H, Golfand EW, et al : Selective gamma $G$ globulin deficiencies in patients with recurrent pyogenic infections. New Engl Med 283:631 634, 1970.

11) Oxelius $V$ : Chronic infections in a family with hereditary deficiency in $\mathrm{IgG}_{2}$ and $\mathrm{IgG}_{4}$. Clin Exp Immunol $17: 19 \sim 27.1974$.

12) Oxelius $V:$ Quantitativc and qualitative investigations of serum IgG subclasses in immunodeficiency diseases. Clin Exp Immunol $36: 112 \sim 116,1979$.

13) Oxelius V, Berkel AI and Hanson LA : $\mathrm{IgG}_{2}$ deficiency in ataxia telangiectasia. Submitted for publication $306: 515 \sim 517$, 1981.

14) Oxelius $V$, Laurell $A B$, Lindquist $B$, et al: IgG subclasses in seledtive IgA deficiency ; prominence of $\operatorname{IgG}_{2}$-IgA deficiency. New Engl J Med 304 : 1476 1477, 1981.

15) Riesen WF, Skvaril $F$ and Braun DG: Natural infection in man with group A streptococci. Levels, restriction in class, subclass, and type and clonal appearance of polysaccharide group specific antibodies. Scand J Immunol $5: 383 \sim 390,1976$.

16) Siber GR, Schur PH, Aisenberg AC, et al: Correlation between serum IgG $_{2}$ concentra- tion and the antibody response to bacterial saccharide antigens. N Engl J Med 303 : 178 182, 1980.

17) Beck CS and Heiner DC : Selective immunoglobulin $\mathrm{G}_{4}$ deficiency and recurrent infections of the respiratory tract. Am Rev Respir Dis 124:94 96, 1981.

18）福嶋義光：Prader-Willi 症候群. 小児科 MOO K 37. 259 266頁, 金原出版, 東京, 1985 .

19）早川 浩, 小林 登, 矢田純一：わが国における Wiskott-Aldrich 症候群の登録症例について. アレルギー $32: 241 〜 252,1983$.

20) Stiehm ER and Fulginiti VA : Immunologic disorders in infants and children 2nd ed. pp 60, Saunders CO, Philadelphia, 1985.

21）松本脩三：免疫ブロブリンの構造と機能. 小児内 科 $17: 1031 \sim 1042,1985$.

22）松本脩三：免疫ブロブリンの分子生物学. 小児 臨床免疫学 (小林 登編)。21頁, 東京医学社, 1975 ,

23) Tojo T, Friou GJ Spiegelberg HL : Immunoglobulin $G$ subclasses of human anti-nuclear antibodies. Clin Exp Immunol $6: 145$ $\sim 151,1970$.

24) Beck OE : Disttibution of virus antibody activity amond human IgG subclasses. Clin Exp Immunol $43: 626 \sim 632,1981$.

25）細井 進: $\mathrm{IgG}_{4}$ とアレルギー疾患. 小児内科 I5:1307 1310, 1973 9.

26) Romer J, Morgenthaler JJ, Scherz R, et al: Characterization of various Immunoglobulin preparation for intravenous application. Vox Sang $42: 62 \sim 73,1982$.

$\left(\begin{array}{l}\text { 原稿採択: 昭和 } 63 \text { 年 } 2 \text { 月 } 23 \text { 日 } \\ \text { 別刷請求先 : 中田順子 } \\ \text { † } 879-56 \text { 大分県大分郡狭間町医大ヶ丘 } 1-1560 \\ \text { 大分医科大学耳鼻咽喉科学教室 }\end{array}\right)$ 